\title{
Specificity of the Culture of Governance in the Mediterranean Arab Countries: A Principal Components Analysis
}

\author{
Najah Souissi ${ }^{1,2} \&$ Messaoud Boudhiaf ${ }^{1,2}$ \\ ${ }^{1}$ Faculté des Sciences Economiques et de Gestion de Tunis, Tunisia \\ ${ }^{2}$ Laboratoire d'Intégration Economique Internationale, Tunisia \\ Correspondence: Najah Souissi, 7 Rue Wahrane Rades Méliène 2040 Tunis, Tunisia. Tel: 216-2060-6547. E-mail: \\ najah_souissi@yahoo.fr
}

Received: January 30, 2014

Accepted: March 11, 2014

Online Published: April 25, 2014

doi:10.5539/ijef.v6n5p64

URL: http://dx.doi.org/10.5539/ijef.v6n5p64

\begin{abstract}
The purpose of this paper is to study the specificity and dynamics of governance culture in the Mediterranean Arab countries. We rely on the notion of governance developed by Meisel and Oueld Aoudia (2007) "Governance for Development" and we use the "Institutional Profiles" database for the years 2001-2006 and 2009. We accomplish a principal component analysis and we show that the institutions of governance prevailing in the Mediterranean Arab countries are not institutionalized and are dominated by interpersonal and informal arrangements. They are also characterized by low capacity of their States to coordinate private interests within the meaning of the general interest.
\end{abstract}

Keywords: governance, national system of governance, Mediterranean Arab countries, formalization of the system of social regulation, coordination capacity of the state

\section{Introduction}

Our purpose in this article is to study the specificity of the culture of governance prevailing in the Mediterranean Arab countries. We adopt a critical approach which contests the notion of "Good Governance" of the World Bank, as supposed solution that corrects deficiencies in economic development models. We show that the "Good Governance" cannot be regarded as a-historical and universal necessity in any development strategy. Furthermore, according to Greif (1993, 1994, 1998), Meisel (2004, 2005), and Meseil and Ould Aoudia (2007), we retain the idea that institutions of governance can't be analyzed regardless of the culture in which they apply, and that institutional change should be approached as an endogenous process in the community, it is based on individual behavior (Note 1). We admit the existence of a multiplicity of cultures of governance and thus a multiplicity of national governance systems. Our work in this article is divided into two sections: in the first section, we define the concept of governance. We show that "Good Governance" cannot generate confidence in all economies regardless of their resources, their stories and their dynamic. Moreover, we adopt a broader concept of governance "Governance for Development" that takes into account the specific institutional arrangements prevailing in a country. In the second section, we use the "Institutional Profiles" database and we accomplish a multivariate descriptive study of different national systems of governance. The identification of such systems depends on how trust, power and information are produced, allocated and exchanged between different individuals. We show that the institutions of governance prevailing in the Mediterranean Arab countries are dominated by interpersonal and informal arrangements and by low capacity of states to coordinate interests within the meaning of general interest.

\section{Governance and National System of Governance}

\subsection{Governance: Origin and Definition}

In the early 1990s, the concept of governance is gaining in importance, to become part of the everyday vocabulary of the major international institutions. Despite the many applications of the term (Note 2), there is a common notion in its use. Indeed, it means "a movement of decentralization of decision-making with a proliferation of places and actors involved in this decision. It refers to the establishment of new forms of regulation more flexible, based on partnership between different actors" (The Free Encyclopedia, 2009). Governance involves several actors and is based on the principle that no actor has more power than another, including the State, which in this approach becomes an actor among others. In this regard, Roseneau (1992) points out that "dealing with 
governance without government, that is to say a system of norms made by the agreement of the majority, which would thus achieving collective project without formal authority and concrete sanction governments". In addition, Rhodes (1996) defines governance as minimal State and a set of self-organized social networks. In this sense, governance can be seen as another name of the minimal State,"a process by which people resolves conflicts and achieve a cooperative solution" (Bsaies, 2006). The World Bank (2003) defines governance as "the exercise of authority in the name of the people", which means the need to involve citizens on an equal basis in the governance process (principle of inclusive) and that they are able to hold their government accountable for the way it makes use of State authority and resources of the people (principle of accountability). In addition, Kaufman and Kraay and Mastruzzi (2007) argue that governance refers to "the traditions and institutions by which authority is exercised for the overall property, including the process by which the authorities are selected, monitored and replaced, the capacity of government to effectively manage its resources and implement sound policies and the respect of citizens and the state for the institutions that govern economic and social interactions among them". For international financial institutions, the role of the State is to ensure the proper functioning of the market economy, that is to say to provide a favorable environment for private investment by reducing production costs, guaranteeing property rights, ensuring political stability and facilitating institutional arrangements. Good governance, where individual rights are respected, secure contracts, effective administration and democratic political institutions, is a universal solution to generate the confidence to begin the process of economic development. It is asked to transition and developing countries to adopt this tool for the development process begin. In their political of economic development cooperation, international donors will need to use their aid as an incentive to the reorganization or reorientation of policies and institutions in recipient countries. Good governance also appears as the guarantor of aid effectiveness for most donors, who believe that the failures of structural adjustment program in many developing countries are due to a deficiency of policy and institutional structures and to an inefficient public management, which is considered as a cause of wasteful of resources and a conversion of public institutions to a narrow circle of loyal and distribution of privileges and private benefits. This public governance is inefficient and it is necessary to substitute it by better governance (Good Governance). But more than a decade, after the forced invitation to them to comply was made, can we say that developing countries have adapted to good governance and the constraints arising from the globalization could undermine the system of governance which organized functioning of these countries and granted to their states a central decision-making power? In other words, is good governance a Good Development Strategy? More fundamentally, can we consider good governance as a-historical and universal necessity in any development strategy regardless of the specifics of the countries concerned?

\subsection{Critique of the Concept of "Good Governance"}

Meisel and Ould Aoudia (2007) show that, if good governance is certainly a powerful factor of confidence in developed countries, it can't produce confidence for all countries independently of their resources, their stories and their dynamics. The authors note a number of constraints faced by developing economies to build the institutions of good governance.

First, a mode of governance based on formal rules involves high fixed costs of investment in legal and judicial infrastructure and organization of monitoring and control. However, in most developing countries, the financial resources are often limited. Furthermore, these organizations must themselves be sufficiently ruled over a sufficiently long period to win the trust of investors. Given the financial, human and temporal constraints they face, the majority of developing countries do not afford this investment in the short or medium term. Then, the formalization of rules is long and complex. Institutional transition, the transition from an informal institutional status to a more formalized institutional state requires to go through phases of uncertainty where the old rules may no longer work, such as loyalty, respect for speech and traditional solidarity while the new rules based on the law and written agreements are not established in the heart of society. The erosion of the traditional system of social regulation leads to a loss of informal safety without any gain in the field of formal security (institutional). Countries cannot advance in this work and get stuck at the threshold of institutional transition.

In addition, the institutions of good governance have been strong resistance from the political and economic elites. In developing countries, most of the recommendations emphasize the importance of having governance institutions supporting the market. It is therefore formal rules where the mode of production of trust, power and information is systemic, conferring rights, including property rights, to all on written and enforceable bases. However, by its formal and universal character, this requirement is the germ of social destabilization and directly threatens the privileges of proponents of social order, the economic and political elites, which derive their power specially from their exclusive access to security of rights and resources. The resistance of interest groups is therefore presented as a blocking factor of institutions. In this regard, North et al. (2007) argue that the study of the 
process of institutional change must be understood in terms of transition of the closed social orders towards opened social orders. The survival and sustainability of the dominant coalition depends on its ability to block access to these new social actors that they could jeopardize their privileges.

Finally, the institutions of good governance cannot explain the performance of some developing countries. Meisel and Ould Aoudia (2007) show that the economic boom experienced by these countries has no direct relationship with the "Good Governance". Countries that share the same level of "bad governance" may have completely opposing economic performance; some have experienced high growth assured them off and the other on the contrary remained trapped in systems of very low growth. The examples of China, Vietnam, Korea, Taiwan and Malaysia, on the one hand, and those of Zimbabwe, Madagascar, Côte d'Ivoire and Venezuela, on the other hand, are these points of view edifying (Note 3). Furthermore, the authors found no significant correlation between foreign direct investment in developing countries and each component of good governance. So that, contrary to the "common wisdom", "Good Governance" is not a major criterion for location decisions of international investors. Countries characterized by low performance in terms of governance receive higher investment flows, while countries with good performance in governance receive little FDI. In addition to traditional factors attracting FDI, the main factor in their attractiveness is the willingness of insiders, political and economic elites in recipient country, to allow or not the entry of newplayer in the market. Insiders oppose the entry of FDI, such as the disregard of property rights and other institutional interlocks, if they perceive the arrival of FDI as a threat to their rent position. By cons, facilities and advantages shall be granted if they have a personal or common interest following their entry.

Therefore, "Good Governance" proposed by the World Bank, cannot be an effective and universal solution for any development program, dice when we adopt a new and expanded concept of governance proposed by Meisel and Ould Aoudia (2007).

\subsection{To a Broader Concept of Governance}

Meiselet al. (2007) have proposed a new and broader governance "governance for development", which takes into account both concept: (i) different institutional arrangements (Note 4) that produce trust between agents, between agents and organizations (State, enterprises) through arrangements taking into account the level of development of each country (governance focal monopoly, formal rules) and (ii) the political economy of systems of social regulation (the opening of system insiders) (Note 5). Based on this broader concept of governance, we assume the existence of several production factors of trust, which vary depending on the level of income and the economic, political and social context of the considered economy. For each factor of production of trust corresponds a system (or similar systems) of governance.

This broader notion of governance "Governance for Development", presupposes that economic development is a multidimensional phenomenon where economic and political factors are interdependent in terms of their effects on society. The transition from poor to rich countries implies radical changes, deep ruptures, causing strong resistance whose outcome is uncertain. Economic policy analysis allows us to understand this type of behavior adopted by the ruling coalition. It designs the decisions and actions of the state as the resulting exchanges made on the "political market" involving different actors (voters, interest groups, politicians and bureaucrats).

Therefore, it is more convenient to expand our traditional view of national systems of governance rather than trying to understand the multitude of existing institutional profiles among developing countries through the single prism of criteria derived from Anglo-Saxon experience. It is possible for each developing country to build its own institutional development model. Governance systems should be understood in terms of their ability to produce "trust" and information (Note 6). Production factors of trust vary by income level and by economic, political and social context of the considered economy. At each trust production factor corresponds a system (or homologous systems) of governance.

\subsection{National System of Governance}

Meisel $(2004,2005)$ distinguishes different institutional systems whose identification depends on how trust, power and information are produced, allocated and exchanged between different individuals. The author suggests that the production of trust depends on:

(i) the degree of formalization of the rules governing the economic, political and social activities. We can then distinguish the systems of governance where the production of trust, power and information is systematic and is based on formal rules and others characterized instead by informal rules and an interpersonal mode of production of trust.

(ii) the ability of the government to change the structure of incentives and information in games of private interests 
so that they also serve the interests of the national community. The existence of adequate instances of deliberation, consultation and coordination permit identification of the "common interest" and its realization. "The role of governance institutions is then to ensure that the field of social interactions is not reducible to a simple game of power relation between different individuals, but allows continually to a common interest to emerged and to be realized" (Meisel, 2005)

We can then distinguish governance systems characterized by a high degree of focus or coordination of private interests in order to achieve a collective interest and others instead characterized by a low degree of coordination and the existence of a multiplicity of focal governance. Four types of national systems of governance can be distinguished:

- Governance systems based on formal and impersonal rules. In such systems, the formalization of rules is an important tool for the production of trust between individuals. These rules apply to all and ignored the intrinsic characteristics of each individual, which ensures a high level of confidence in their respect and enforcement. This method of producing confidence characterizes developed countries that have experienced a long process of depersonalization of social relations and formalization of rules. Production of trust can be described by systemic.

- The governance systems based on personal relationships: In such systems, the trust in the relationship to power, in the flow of information and in the rules are made and shared according to the specific characteristics of individuals or their belonging to a group (family, ethnic) of limited size by definition. Such a system characterizes many developing countries in the years 1950-1960, which were early in their industrialization process. Nevertheless, as the population grew and the economy is opened and integrated with the regional and global economy, traditional production system of trust has become unsustainable. Using a system of depersonalization of social, economic and political regulations became inevitable. Indeed, local actors are engaged in commercial and financial transactions with foreign players, who are accustomed to systems based on formal rules, where high levels of trust and information produced by the system itself.

- The systems of governance based on the existence of a governance focal monopoly. These types of organization are based on the existence of a state that has the ability, with varying degrees, to coordinate, the relationships between interest groups prevailing at different levels of society, at international, national and local levels in order to exceed oligopolistic struggle between these groups for access to rents and achieve the highest possible common interest. The power of a governance focal monopoly depends on its ability to coordinate the interests and influence the private logic of special interest coalitions in the direction of the general interest in the long term, so that stakeholders are not only interested in what think or what is going to do the other (pure strategic rivalry), but they think about a stable and unique solution can be established. If the focal monopoly is powerful enough, it can ensure that the public interest is taken into account by each of the interest groups even in developing its strategy.

Hence it changes the structure of incentives and information in games of particular interests, so as a result that interest groups serve a much wider interest than their own. Therefore it acts directly on growth by reducing transaction costs and ensuring security expectations for agents.

Several historical experiences illustrate the operation of governance focal monopoly. South Korea has realized its economic takeoff during the period 1960-1990 with a strong coordinator and anticipatory State. The France of the "thirty glorious years" also had a highly coordinator-anticipatory State, allowing it to provide very high economic performance since the end of World War II until the early 1970s. Furthermore, the majority of the reforms in China have produced good results from 1978 thanks to special attention paid by the government to the interests of different social actors involved in the reform processand, in particular, interest groups individuals.

- The governance systems based on crony capitalism.

This system corresponds to a situation where the political and economic elites are strongly linked. Such a system characterizes economies that are vulnerable to political instability phenomena due to conflicts between coalitions of special interests, so that the option of focal monopoly, of coordination and institutionalized dialogue seem to deviate. For these countries, a system based primarily on the "cronyism", offers a solution much cheaper and easier to implement. The solution is to involve government officials or their relatives to the income produced by the asset owners in the exploitation of resources. Political and administrative elites accordingly provide a "broadly inclusive" interest (encompassing) in the rents generated by the economy.

It should be noted that such a system of governance characterizes the majority of developing economies. It is a priori an inexpensive solution and seemingly beneficial to economic growth but it has serious limitations. In order to establish legitimacy of political leaders, such a system of governance can initiate or ensure the growth of some macroeconomic aggregates (such as increased investment or gross domestic product) but does not guarantee 
economic development or sustainability of this growth over a long period. In this regard Ouel Aoudia (2006), Souissi $(2013,2014)$ show thata system of governance characterized by a strong collusion between economic and political elites is an obstacle to their economic takeoff and their convergence to advanced economies. Furthermore, Benali (2004), Diallman (2001), El Morched (2008), Catusse (2009), Gobe (2007) show that during the implementation of reforms, the political class in most developing countries day to prevent the risk of a strong opposition. Its main objective is the search for greater legitimacy ensuring their continued power. For this, it develops clientelistpoliciesand distributesprivilegesand benefits. More stakeholders and interest groups claim, the more they threaten the détenants of political power and the more they get privileges. In this sense, works are multiplied onthe formation ofcoalitionsbetweenpolitical and economic elitesand the emergenceof winners andlosersofadjustment policies.

\section{The Specificities of National Systems of Governance in the Mediterranean Arab Countries: A Principal Components Analysis}

The principal component analysis (PCA) is a statistical instrument that is used to extract the information in a database consisting of a set of individuals, characterized by a high number of variables roughly correlated.

It offers a representation of individuals on factorial designs with two dimensions (only representable). The axes are in fact built on the basis of linear combinations of variables and variance of all observations. They are classified according to the level of variance of the point cloud that it can focus. The first axis is the one that captures the most variance of the point cloud formed by the set of variables, then the second, etc. The interpretation of the first two axes is crucial in the factor analysis. It is done mainly on the basis of the identification of variables that contribute most to the definition of the axes in question. By this method we try to locate countries on a factorial design to identify governance systems characterized by all countries reviewed, in particular the Mediterranean Arab countries.

This work is inspired from Meisel (2004), whose theoretical assumptions have not yet been empirically verified. The author suggests the existence of a multiplicity of cultures of governance, every culture is characterized by the way that the trust, the power and information are produced, organized and shared.

We consider the two modes of production of confidence indicated above:

-The formalization of the system of social regulation and

-The governance focal monopoly.

Meisel and Oueld Aoudia (2007, p. 43) have proposed two sets of indicators that reflect these institutional aspects. Concerning the indicators of formalization of the system of social regulation, the variables are: (1) the effectiveness of the public administration, (2) control of corruption, (3) the security of formal property rights, (4) security transactions on the markets for goods and services and financial markets, (5) the security of rights and property transactions, (6) institutional solidarity, (7) the regulation of the financial system, (8) compliance labor law. Regarding the indicators of coordination and anticipation, we consider the following variables: (1) the ability of the state to facilitate forms of collaboration to emerge a common interest, (2) the capacity for autonomous decision of the State (3) the priorities of elite development, (4) coordination within and between governments, (5) the ability of political authorities, (6) the authorities' strategic vision, (7) the ability of the company for Innovation, (6) technological business environment, (8) investment in the future of the population, (8) technological environment, (9) venture capital.

Detailed or elementary questions that correspond to our indicators cited above are mentioned in Appendix A.

The availability of the database "Institutional Profiles" for the years 2001-2006 and 2009 gives us the opportunity to conduct a comparative study of the specificity of governance systems in the Mediterranean Arab Countries for the years 2001, 2006 and 2009. We have 55 countries for the year 2001, 85 countries in 2006 and 129 countries in 2009. We use disaggregated data (items) of each of the bases. We have 28 elementary variables for the year 2001, 40 elementary variables for 2006 and 52 elementary variables for the year 2009 (see Appendix A).

The application of the method of principal component analysis (Note 7) on each of the databases of 2001, 2006 and 2009 allows us to obtain results (outputs) respectively presented in Appendix B, C and D.

We discuss below the results of the year 2001. It is the same comment for the years 2006 and 2009:

-The test of sphericity of Barlett (Table1 below) shows a significant absence of spherical model. In fact, if the model is spherical, we can assume that the correlations between the variables areclose to zero and thusthere isno incentive to replace the variables with the components. The observed value must be less thanor equal to 0.05 . In our case, the meaning is equal to 0.000 , which means that the hypothesis $\mathrm{H} 0$ is rejected, that is to say that there's 
a significant lack of sphericity and we can therefore continue to study the principal components of governance. In addition, the test Kaiser-Meyer-Olkin (KMO), which is a generalized measure of the partial correlation between the study variables, shows that the principal components factor analysis of governance systems is of high validity (with a measure equal to 0.899) (Note 8).

Table1. Index KMO and Barlett test

\begin{tabular}{lll}
\hline \multicolumn{2}{l}{ Kaiser-Meyer-Olkin Measure of Sampling Adequacy. } &, 899 \\
\hline \multirow{3}{*}{ Bartlett's Test of Sphericity } & Approx. Chi-Square & 1155,581 \\
& Df & 378 \\
& Sig. &, 000 \\
\hline
\end{tabular}

Note. Survey 2001.

- Table B1 of Appendix B shows the most important components (or factors) according to their degree of inertia. There are so many factors as variables. Only those components with eigenvalues greater than 1 are selected (there are 6 components) (Note 9). In our factorial design, we retain the first two factors, those which concentrate the maximum amount of information contained in our database; it is $51.894 \%$ for the first factor and $7.642 \%$ for the second factor.

- Table B2 of Appendix B provides the matrix components after rotation (Note 10). There are coefficients of different variables with respect to each component. The variables that contribute to the formation of a factor are those that have the highest coefficients of this factor. In fact each variable can be presented by the following expression:

With, $a_{i j}=$ the coefficient of the variable $i$ associated with factor $j$;

$$
X_{i}=a_{i 1} F_{1}+a_{i 2} F_{2}+\ldots . . a_{i n} F_{N}
$$

$N=$ Number of factors.

The variable $\mathrm{Xi}$ will be captured by the factor whose coefficient is the highest. Moreover, it is noted that the sum of the square of the coefficientsaij, ie $\left(\sum_{i=1}^{n} a_{i j}^{2}\right)$, gives the weight of the variable $\mathrm{i}$ or the part of the variance explained by the $\mathrm{n}$ factors. $\left(a_{i j}^{2} / \sum_{i=1}^{n} a_{i j}^{2}\right)$, represents the hand of the variance of the variable $\mathrm{i}$ sensed by the factor $\mathrm{j}$. Factor $\mathrm{j}$ captures the variables having the highest information on this axis.

Given that the factor $F_{j}$ may be presented by the following expression:

$$
F_{j}=\sum_{i=1}^{p} w_{j i} X_{i}=w_{j 1} X_{1}+w_{j 2} X_{2}+\ldots w_{j p} X_{p}
$$

With $w_{j i}=$ the coefficient of the variable $I$ associated with the factor $\mathrm{j} . p=$ the number of variables

The weight of the factor $\mathrm{j}$ or the variance of the factor $\mathrm{j}$ is given by the sum of the square of the coefficients of the factor $\left(\sum_{i=1}^{p} w_{j i}^{2}\right)$. Variance of factor $\mathrm{j}$ relative to the sum of the variance of the three factors gives the degree of inertia or the part of the variance of each factor; it is $51.894 \%$ for the first factor and $7.642 \%$ for the second factor.

We consider the Table 2 below, which takes account of variables in the database that have contributed to the formation of the first two axes. We distinguish two families of variables, those who have the highest correlation coefficients with respect to the axis 1 and those with the highest correlation coefficients with respect to axis 2 . We note that the variables A3020, A3021, A3041, A3043, A6010, A6011, A6012 and A6013 are among all variables in the database, those who have the most weight in the formation of axis 1 and variable A5110, A5150, B5000 and B5001 those who have the most weight in the formation of axis2. 
Table 2. Description of the first two axes by the active variables of the PCA for 2001

\begin{tabular}{|c|c|c|c|}
\hline Variables & Labels of variables & Component 1 & Component2 \\
\hline A3020 & Level of "petty" corruption (between citizens and the administration) & 0.679 & \\
\hline A3021 & Level of "large-scale" corruption (between the administration and firms) & 0.415 & \\
\hline A3041 & Importance of tax evasion in the formal sector & 0.502 & \\
\hline$A 3043$ & Capacity of the tax administration to implement measures decided on & 0.497 & \\
\hline A6010 & Effectiveness of legal measures to defend property rights between private agents & 0.633 & \\
\hline A6011 & $\begin{array}{l}\text { Compensation in the event of de jure or de facto expropriation (by the } \\
\text { Government) of real property }\end{array}$ & 0.804 & \\
\hline A6012 & $\begin{array}{l}\text { Compensation in the event of de jure or de facto expropriation (by the } \\
\text { Government) of instruments of production? }\end{array}$ & 0.778 & \\
\hline$A 6013$ & $\begin{array}{l}\text { Generally speaking, does the government exert arbitrary pressure on private } \\
\text { property (red tape, etc)? }\end{array}$ & 0.745 & \\
\hline A5110 & Society's aptitude for technological adaptation and innovation & & 0.683 \\
\hline A5150 & Do parents invest a great deal in their children's education? & & 0.654 \\
\hline$B 5000$ & Proportion of technical staff (engineers, technicians) insmall and medium firms. & & 0.547 \\
\hline B5001 & Proportion of technical staff (engineers, technicians) in large firms & & 0.531 \\
\hline Variance in $\%$ & & $51.894 \%$ & $7.642 \%$ \\
\hline $\begin{array}{l}\text { Cumulative } \\
\text { variance in\% }\end{array}$ & & $51.894 \%$ & $59.535 \%$ \\
\hline
\end{tabular}

Variables that have contributed to the formation of the first axis reflect:

- The corruption that is apprehended by the A3020 and A3021 indicators;

- The efficacy of public policy and in particular the efficacy of fiscal systems, captured by variables A3041 and A3043;

- Security of formal properties rights seized by the variables A6010, A6011, A6012 and A6013;

In addition, variables that have contributed to the formation of the second axis take into account:

- The ability of the society to adaptation and innovation, captured by the variable A 5110;

- The investment in the future of the people, apprehended by the variable A5150;

- The technological environment and the diffusion of technology, captured by the variables B5000 and B5001.

The family of indicators having contributed to the construction of the first factor defines the degree of personalization in the functioning of governance institutions and those who contributed to the construction of the second factor define the level of coordination and anticipation (Note 11).

The first factorial plane derived from the principal component analysis and applied to 55 countries of the survey of MINEFE of 2001, is shown in Figure 1 below. This plan isbuilt from thefirst twoaxesof dispersion of variables revealed (Note 12).

- The first axis (vertical) that captures the most information contained in our base (i.e., $51.894 \%$ of the total information) opposed two types of governance culture, namely the degree of "personalization versus depersonalization" in the functioning of governance institutions. This axis then discriminates between countries according to their degree of formalization of institutions. To the north of this axis, there are situated countries having governance systems characterized by highly formalized rules ie written and enforceable rules. Also, they are endowed with systems that ensure a high compliance with these rules: an efficacious and transparent administration, a security of transactions and property rights. On the south of this axis, focus systems marked mainly by informal links trust where formal control mechanisms are limited or poorly respected. The United States today can be located relatively on the high (north) of this axis because of their high level of formal regulation.

- The second axis (horizontal) captures $7.642 \%$ of the total variance and reflects the degree of "anarchy versus hierarchy" in the interaction of interests in a given country. To the left (west) are systems characterized by a multiplicity or a proliferation of potentially conflicting focal points of governance. The probability that any form of common interest emerge is low and the field of interaction of interests is likely to become a pure power game. Moving to the right (East), there are more hierarchical systems, characterized by a focal point of governance or a governance focal monopoly. 
Figure 1, outcome of our PCA, shows that all countries are divided into four groups according to the institutional characteristics of their governance systems. In the area North-east of Figure 1, are positioned countries characterized with a relatively high degree of institutional formalization, as well as having an ability to coordinate interests in the direction of the general interest. Countries like Canada, Britain, the United States, Germany and Ireland are positioned towards the top of the quadrant indicated. These countries are characterized by a culture of governance based essentially on the formalization of rules and ensure high levels of trust, power and information as part of their normal operation. Their production of trust is called "systemic". In the North-west area of Figure 1 are positioned countries characterized by relatively formalized governance institutions and having a plurality of focal points of governance, for example Morocco and Egypt. Both countries are located in the North-west quadrant of the area, so they stand out compared to other Arab countries in the Mediterranean by a system of social control relatively formalized. In quadrants South-east and South-west are positioned countries with cultures of governance based on interpersonal and informal relationships. There are essentially countries in transition and developing countries. In the south-western part are localized countries characterized by a multiplicity of focal points of governance. The absence of a single focal point generally reflects the weak role of the State in the coordination of special interests. Algeria and Syria are located in this area. In these economies, the scope of interaction of interests is likely to become a pure power game without any form of general interest manages to emerge. Tunisia is located in the Southeast area and stands out compared to other Mediterranean Arab countries by a certain ability of the state to coordinate the interests in favor of the public interest. The system of governance prevailing in Tunisia in 2001 is governed by a governance focal monopoly.

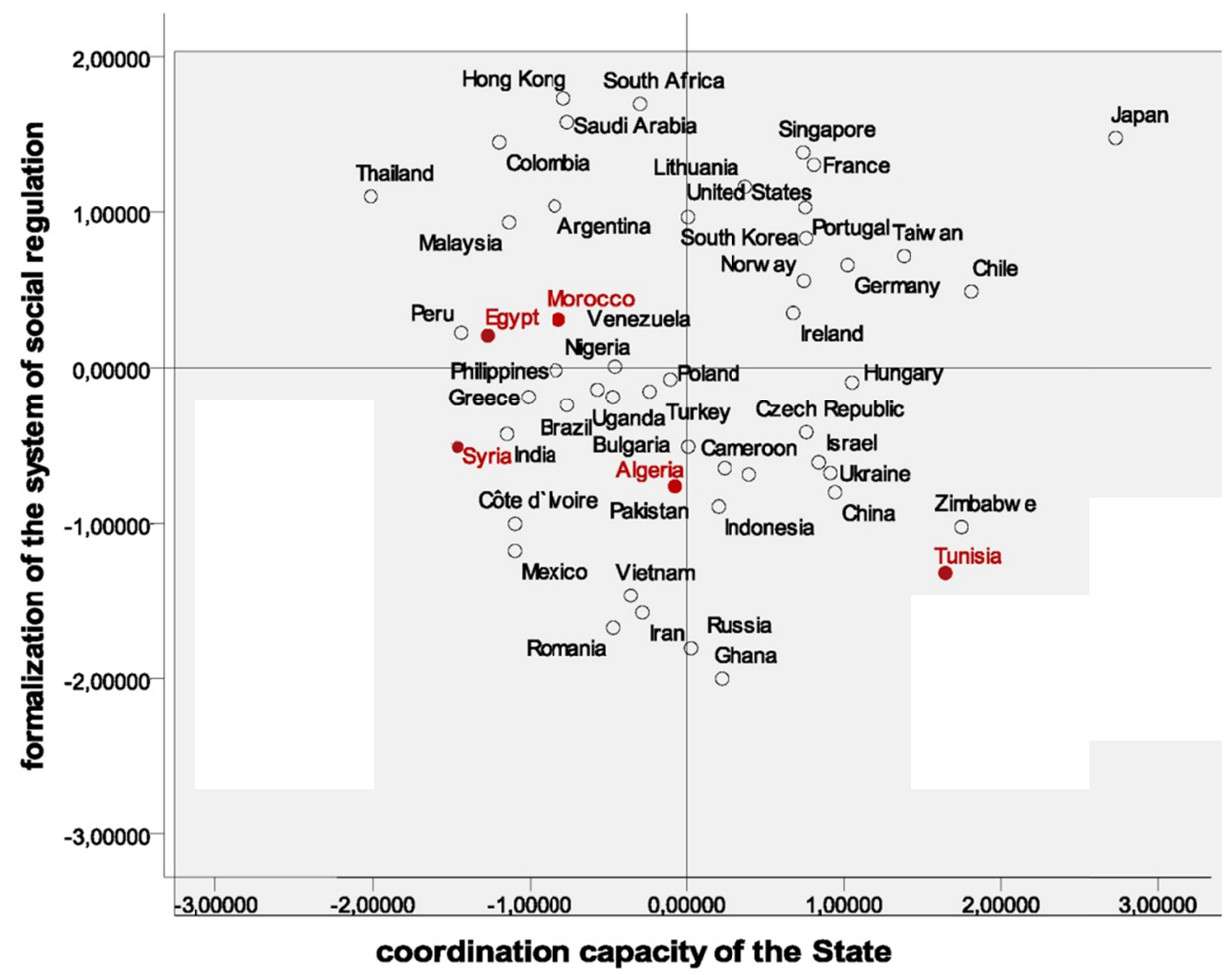

Figure 1. Diversity of national systems of governance in 2001

Source: authors from (Institutional Profiles) database of 2001.

The projection of different individuals from the 2006 and 2009 surveys on the first factorial plane from the PCA are represented respectively by Figures 2 and 3 below. 


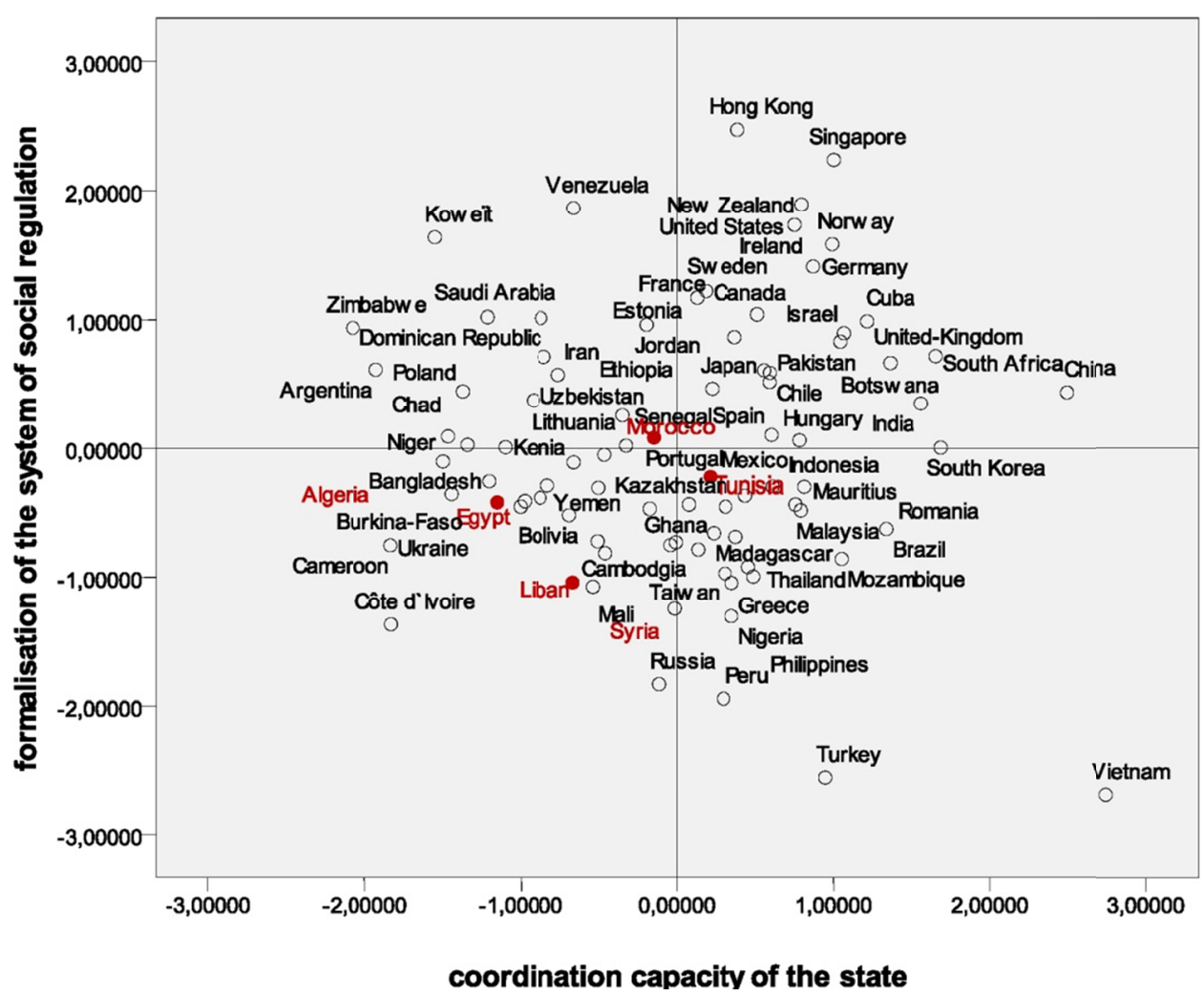

Figure 2. Diversity of national systems of governance in 2006

Source: authors from (Institutional Profiles) database of 2006.

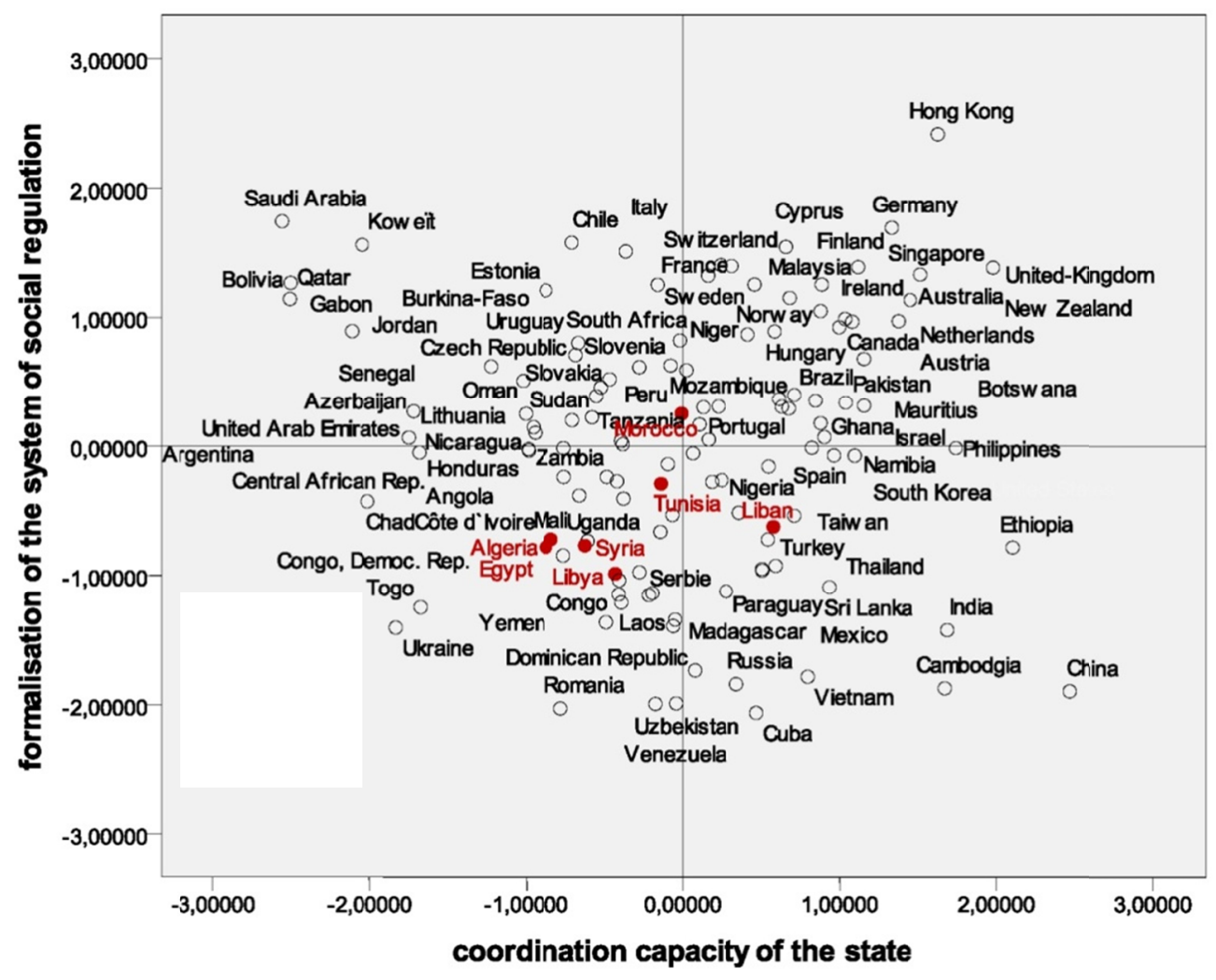

Figure 3. Diversity of national systems of governance in 2009

Source: authors from (Institutional Profiles) database of 2009. 
As a result, if Figure 1 shows that in 2001 the Mediterranean Arab countries are characterized by a diversity of national systems of governance. Figures 2 and 3, which respectively describe the specificities of national systems of governance in 2006 and 2009, show that with the exception of Lebanon (who shows a transition to a governance focal monopoly in 2009), the Mediterranean Arab countries converge towards a system of informal social regulation and a multiplicity of focal points of governance. In fact, Egypt is experiencing a degradation of its production of confidence and moves to the Southwest quadrant area, its system of social regulation has become essentially based on personal relationships. Similarly, Tunisia, in 2006 still located in the area south-east of framing but towards the southwestern quadrant and approximates the center. In 2009, it is located in the Southwest quadrant of the chart. So the existence of a government with the ability to coordinate actors and secure expectations is no longer the case in Tunisia. In fact, more the country is facing west, more the option of focal monopoly seems to recede and more it is exposed to political instability phenomena due to conflicts between coalitions of special interests. Morocco is still located in the northwest area of the graph but it approaches to the center. Its production of trust, based on formal and impersonal rules in 2001, is weakened. Algeria and Syria (the Libya in 2009) maintain their positions on the charts, compared to 2001. Their Governance systems are fundamentally based on personal relationships and are characterized by low capacity of States to coordinate private interests and to develop a strategic vision for the development and sharing beyond insiders.

So the formalization of rules cannot be an important lever for producing confidence in the Mediterranean Arab countries. Similarly, the existence of a government with the capacity to coordinate actors and secure expectations cannot be the case for these economies. In this case a "crony system" appears to be much less expensive and easier to implement, in short more realistic option (Note 13).

In summary, the results of our principal component analysis showed that the Arab Mediterranean countries are characterized by:

1) Governance institutions bit institutionalized and dominated by interpersonal and informal arrangements (with the exception of Lebanon).

2) A multiplicity of special interest coalitions and low capacity of states to coordinate private interests within the meaning of general interest.

3) The capitalism cronyism or the interweaving of public and private interests is a priori an inexpensive solution and not necessarily antagonistic to economic growth. Such a situation allows establishing legitimacy of political leaders. This legitimacy is ensured by a certain ability to initiate the development of the country or the achievement of high rates of economic growth (e.g., Tunisia and Morocco) (Note 14).

However, the predominance of closed social orders, held by economic and political elites is the basis of resistance to institutional reforms and the transition to market economy and democracy.

\section{Conclusion}

The wealth of institutional data base of MINEFE has allowed us to identify different systems of governance in a set of developing countries, transition and developed. This is an illustration or a concretization of the concept of national systems of governance, developed by Meisel (2004). This database also allowed us to know the characteristics of the governance system prevailing in the Mediterranean Arab countries. The principal component analysis allowed us to identify the main discriminating factors, distinguishing countries by two dominant components: (i) the degree of formalization and depersonalization of governance systems on the one hand, and (ii) the degree of coordination of interests in favor of the public interest on the other hand. Location of different countries selected on the factorial design allowed us to identify different systems of governance. The Mediterranean Arab countries are among the countries that are still marked by the predominance of interpersonal arrangements and informal rules. They are marked by a low capacity for States to coordinate their individual interests or a multiplicity of focal points of governance. Except Lebanon, which converges to a governance focal monopoly in 2009, the other Mediterranean Arab Countries show a particularly strong governance deficit. We observe a quasi-absence of any mode of production of trust (formalized institutional system and governance focal monopoly). In these countries a "crony system" their appears a much less expensive and easier to implement, brief more realistic. However, the predominance of such a system is blocking the transition to market and democracy in the Mediterranean Arab countries. In this context, Nabli (2008) shows that the strong coalition between economic and political elites in Arab countries will block any institutional reform (progression of the rule of law) in these economies due to the resistance of the beneficiaries of the status quo and a self-sustaining imbrications of their public and private interests, on the one hand and a weak mobilization of the structure of social forces in these economies, on the other hand. Ben Abdelkader (2009) shows that the influence of the 
dominant clan of the sources of power in the Mediterranean Arab countries is strengthened and paralyzes any form of collective action. El Morched (2008) shows that Morocco for example has in recent years deep political and institutional restructuring to make favorable conditions to the emergence of a market economy, to clean up the political and social environment and establish the rules of good governance. The first result of these reforms reveals some important achievements, such as the strengthening of human rights, the modernization of the judicial system, broadening the scope of freedom of expression, the attempt to moralize public life and the introduction of multiparty politics. However, the weak capacity of expertise of the reformers, the lack of constructive debate and asymmetric information have given rise to a rent-seeking behavior and a dynamic trading between various social groups rent-seeking (the bourgeoisie affiliated with the ruling political class, bureaucrats, political parties).

The consequence of such a situation of institutional blockage is the accumulation of tensions through the society that could cause an episode of violent and brutal destabilization. The requests to participate of social and community organizations, when not satisfied adequately, become the origin of many conflicts. Current social movements in the Arab economies demonstrate such a conclusion. Their goal is to develop robust, transparent and responsible governance institutions, based on respect for the rule of law.

\section{References}

Ben Abdelkader, F. (2009). Du droit de l'Etat à l'Etat de droit dans les pays arabes de la Méditerranée. Thèse de doctorat en sciences économiques, Université Pris 1 Panthéon Sorbonne.

Benali, D. (2004). La monarchie et la transition démocratique: Interviews. Editions Alahdath Almaghribia.

Bsaies, A. (2006). Mondialisation, gouvernance et autonomie. Faculté des Sciences Economiques et Gestion de Tunis, article non publié.

Catusse, M. (2009). A propos de l'Entrée en Politique des (Entrepreneurs) Marocains. Nakd, 14.

El Morched, B. (2008). Recherche de Rente et processus de Réformes Politiques et Institutionnelles dans le Monde Arabe: La leçon Marocaine. Equity and Economic Development, ERF 15 th Annual Conference 23-25 Novembre, 2008.

Gobe, E. (2007). Secteur privé et pouvoir politique en Egypte: Entre réformes économiques, logiques rentières et autoritarisme néo-patrimonial. In D. K. Gérard \& M. Nadine (Eds.), Etats et sociétés de l'Orient arabe en quête d'avenir 1945-2005 (pp. 253-265). Paris, Geuthner: Dynamiques et enjeux II.

Greif, A. (1993). Contract enforceability and economic institutions in early trade: The maghribi traders coalition. The American Economic Review, 83(3), 525-548.

Greif, A. (1994). Cultural beliefs and the organization of society: A historical and theoretical reflection on collectivist and individualist societie. The Journal of Political Economy, 102(5), 912-950. http://dx.doi.org/10.1086/261959

Greif, A. (1998). Historical and comparative institutional analysis. The American Economic Review, 88(2), 8084.

Kaufmann, D., Kraay, A., \& Mastruzzi, M. (2007). Governance matters VI: Governance indicators for 19962006. World Bank Policy Research Working Paper No 4280. The World Bank.

Meisel, N. (2004). Culture de gouvernance et développement. Intérêt de l'expérience française dans la gouvernance des entreprises pour les pays en développement et les économies émergentes. Paris: Editions de l'OCDE. http://dx.doi.org/10.1787/9789264017306-fr

Meisel, N. (2005). Un autre regard sur la gouvernance d'entreprise (pp. 14-24). Problèmes économiques No 2868.

Meisel, N., \& Ould, A. J. (2007). La 'Bonne Gouvernance' est-elle une bonne stratégie de développement. Documents de travail de la DGTPE.

Nabli, M. K., Silva-Jáuregui, C., \& Aysan, A. F. (2008). Autoritarisme politique, crédibilité des réformes et développement du secteur privé au Moyen-Orient et en Afrique du Nord. Revue D'économie Du Développement, 22(3), 49-85. http://dx.doi.org/10.3917/edd.223.0049

North, D. C. (1990). Institutions, institutional change and economic performance. Cambridge: Cambridge University Press. http://dx.doi.org/10.1017/CBO9780511808678

North, D. C., Wallis, J. J., Webb, S. B., \& Weingast, B. R. (2007). Limited access orders in the developing world: 
A new approach to the problems of development. World Bank Policy Research Working Paper No. 4359. http://dx.doi.org/10.1596/1813-9450-4359

Ould, A. J. (2006). Croissance et réformes dans les pays Arabes Méditerranéens. Agence Française de Développement Département de la Recherche.

Pigott, L. (2005). Tribalism in the Arab MENA Region. Policy, 21(1), 15-20.

Rhodes, R. A. (1996). The new governance: Governing without Government. Political Studies, 44, 652-667. http://dx.doi.org /10.1111/j.1467-9248.1996.tb01747.x

Roseneau, J., \& Czempiel, E. O. (1992). Governance without government: Order and change in world policies. In G. Stoker (Ed.), Cinq propositions pour une théorie de la gouvernance (Vol. 155, pp. 19-30). Revue internationale des Sciences Sociales.

Souissi, N. (2013). Gouvernance publique et croissance économique dans les pays arabes de la méditerrané. Thèse de doctorat en sciences économiques, Faculté des Sciences Economiques et de Gestion de Tunis.

Souissi, N. (2014) Governance and economic convergence in the Mediterranean Arab countries. International Journal of Economics and Finance, 6(1), 66-81. http://dx.doi.org/10.5539/ijef.v6n1

World Bank. (2003). MENA development report: Better governance for development in the Middle East and North Africa. Washington, DC: The World Bank.

\section{Notes}

Note 1. "The formal system of governance reached by the developed countries is the result of a long and gradual process that began in Europe since the eighteenth century, leading to the affirmation of the free individual and the organization of society in democracy"Meisel (2005).

Note 2. In economics, in management, in political sciences, etc.

Note 3. In this regard, Meisel and OuldAoudia have used the (Institutional Profiles database and have identified key institutional factors that distinguish developing countries with high growth of those whose growth is slow. It is the ability of the State to offer actors credible forms of coordination, management of conflicting interests, driving population towards risk taking and achieving a common good higher than the sum of individual interests. In other words, it's the ability of the State to reduce uncertainty and to disseminate confidence to all agents. It is a focalization of private interests in favor of the public interest. This capability constitutes the priority element of governance, on which developing countries should focus their efforts to approach, in a first time, characteristics of developed countries. In a second step, the acquisition of confidence factors characterizing these latter, namely the highly formalized rules, can be favorably adopted and make sustainable growth in the long term. These modes of organizations are called (governance focal monopoly) and characterize some developing countries have experienced phases of strong acceleration and sustained growth (the countries of East Asia and South East in particular).

Note 4. The authors have adopted the definition of institutions of North (1990): institutions are constituted by a set of formal rules (constitution, laws and regulations, political system) and informal rules (value systems and beliefs, social norms) which regulate the behavior of individuals and organizations (companies, trade unions, NGOs).

Note 5. It is an opening of the system of economic regulation (widening of entry capacity on the market to new players), of social regulation (increased role of merit), and of political regulation (democracy).

Note 6. In fact, according to what has been mentioned above, the effectiveness of an institutional system depends on its ability to produce confidence.

Note 7. By using the software SPSS.

Note 8. Reading the KMO test is as follows:

-0.90 and higher $=$ very high validity;

-0.89 to $0.80=$ high validity;

-0.79 to $0.70=$ average validity;

-0.69 to $0.60=$ low validity;

-0.59 to $0.50=$ validity threshold limit; 
-0.49 and less $=$ invalid;

Note 9. In fact, most statistical software adopted for the selection of factors, the Kaiser criterion. This criterion retains factors whose explained variance (eigenvalue or inertia) is equal to or greater than 1. Components having a value less than 1 will be rejected. See on this subject G. FERGUSON (1971), Statistical Analysis in Psychologie, New York, McGraw Hill, pp. 421-425.

Note 10. In fact, by construction, factors are orthogonal (so they are uncorrelated). Methods for orthogonal rotation (varimax) preserve the condition of orthogonality of factors.

Note 11. Recall that, each of these two families of indicators belongs to a larger family of indicators describing an institutional aspect, defined by Aoudia Ould and Meisel (2007). These are the formalization of thesystemof social regulation and the coordination of private interests in favor of general interest.

Note 12. The application of the method of principal component analysis using the aggregated variables of data base offers the same results.

Note 13. However, it should be noted that the "cronyism" may appear in any culture of governance without becoming the dominant trait. In fact, a mode of production of formal and impersonal trust will be less exposed to the risk of spreading a culture of "cronyism" through the institutions of national governance.

Note 14. For other oil producing countries (such as Algeria or Syria) the establishment of a crony capitalism or partial redistribution of oil revenues (grants commodities in particular) provides some legitimacy to politicians without greater accountability from them (Ben Neffissa, 2002; Ben Abdelkader, 2009).

\section{Appendix A}

\section{Overview of the Contents of Selected Institutional Variables}

We present below the MINEFI issues that led to the elementary variables, from which we have built our governance indicators survey. We expose it according to its institutional themes.

Table A1. Formalization of the system of social regulation

\begin{tabular}{|c|c|c|}
\hline A302 & Corruption & $1=$ high level to $4=$ low level \\
\hline A3020 & Level of "petty" corruption & From 1 to 4 \\
\hline A3021 & Level of "large-scale" corruption & From 1 to 4 \\
\hline A304 & Effectiveness of public action: fiscal system & $\begin{array}{l}\text { from } 1=\text { large informal economy, generalized tax and customs } \\
\text { evasion to } 4=\text { small informal economy, little tax and customs } \\
\text { evasion }\end{array}$ \\
\hline A3040 & weight of the informal economy & From 1 to 4 \\
\hline A3041 & weight of tax evasion in the formal sector & from 1 to 4 \\
\hline A3042 & weight of customs evasion & from 1 to 4 \\
\hline A3043 & $\begin{array}{l}\text { Capacity of the fiscal administration to apply measures } \\
\text { decided on }\end{array}$ & from $1=$ low capacity to $4=$ high capacity \\
\hline A601 & Security of property rights & from 1 to 4 \\
\hline A6010 & $\begin{array}{l}\text { Efficacy of legal means to protect property rights between } \\
\text { private agents }\end{array}$ & from $1=$ weak legal means to $4=$ very effective legal means \\
\hline A6011 & $\begin{array}{l}\text { Recompense in cases of expropriation by the State of law or de } \\
\text { facto of real property (land)? }\end{array}$ & from 1 = no recompense to $4=$ "reasonable" recompense \\
\hline A6012 & $\begin{array}{l}\text { Recompense in cases of expropriation by the State of law or de } \\
\text { facto of instruments of production? }\end{array}$ & from $1=$ no recompense to $4=$ "reasonable" recompense \\
\hline A6013 & $\begin{array}{l}\text { In general, does the State exert arbitrarypressureon private } \\
\text { property(red tape ...)? }\end{array}$ & $\begin{array}{l}\text { from } 1=\text { very prevalent arbitrary pressure to } 4=\text { no arbitrary } \\
\text { pressure }\end{array}$ \\
\hline A904 & Institutional solidarity & $\begin{array}{l}0 \text { if no coverage by public or private institutions for sickness, } \\
\text { unemployment, retirement - If coverage exists, grade from } \\
1=\text { small proportion of population covered to } 4=\text { very large } \\
\text { proportion of population covered }\end{array}$ \\
\hline A9040 & Sickness coverage & from 0 to 4 \\
\hline A9041 & Unemployment coverage & from 0 to 4 \\
\hline A9042 & Retirement coverage & from 0 to 4 \\
\hline
\end{tabular}




\begin{tabular}{|c|c|c|}
\hline B607 & Protection of rights and land transactions & from 1 or 0 to 4 \\
\hline B 6070 & $\begin{array}{l}\text { Are agricultural land property rights mostly traditional } \\
\text { (informal or quasi-informal) or are they formal? }\end{array}$ & from 1 to 4 \\
\hline B6071 & $\begin{array}{l}\text { Is the protection of TRADITIONAL property rights and } \\
\text { transactions guaranteed? }\end{array}$ & from 0 to 4 \\
\hline B 6072 & $\begin{array}{l}\text { Is the protection of FORMAL property rights and transactions } \\
\text { guaranteed? }\end{array}$ & from 1 to 4 \\
\hline C701 & Regulation of competition in the banking system & $\begin{array}{l}0 \text { if no arrangements }- \text { if arrangements, grade from } 1=\text { very } \\
\text { low effectiveness to } 4=\text { high effectiveness }\end{array}$ \\
\hline $\mathrm{C} 7010$ & $\begin{array}{l}\text { Existence of arrangements to combat restrictive collective } \\
\text { agreements }\end{array}$ & from 0 to 4 \\
\hline C7011 & $\begin{array}{l}\text { Existence of arrangements to combat abuse of dominant } \\
\text { position }\end{array}$ & from 0 to 4 \\
\hline D601 & Existence and observance of labour legislation and measures & $\begin{array}{l}0 \text { if no laws or arrangements - if laws or arrangements exist, } \\
\text { grade from } 1=\text { no observance to } 4=\text { observance }\end{array}$ \\
\hline D6010 & Minimum wage & from 0 to 4 \\
\hline D6011 & Dismissal procedures & from 0 to 4 \\
\hline
\end{tabular}

Table A2. Coordination-anticipation

\begin{tabular}{|c|c|c|}
\hline A505 & $\begin{array}{l}\text { Consultation structures animated by the political power in order } \\
\text { to find a common interest between actors }\end{array}$ & from 0 to 4 \\
\hline A 5050 & $\begin{array}{l}\text { Does the political power anime consultation structures between } \\
\text { the main actors? }\end{array}$ & from 0 to 4 \\
\hline A506 & Government capacity for autonomous decision-making & from 1 to 4 \\
\hline A5060 & $\begin{array}{l}\text { Does the political authority have an autonomous decision-making } \\
\text { capacity compared with the different stakeholders? }\end{array}$ & from 1 to 4 \\
\hline A508 & Co-ordination between ministries and within the administrations & from 1 = weak co-ordination to $4=$ strong co-ordination \\
\hline A5080 & Co-ordination between ministries & from 1 to 4 \\
\hline A5081 & Co-ordination within the administrations & from 1 to 4 \\
\hline A510 & Capacity of the political powers & from $1=$ low levels of capability, to $4=$ high levels \\
\hline A5100 & $\begin{array}{l}\text { Capacity of decision making of political powers in economic } \\
\text { matters (competence, ...) }\end{array}$ & from 1 to 4 \\
\hline A5101 & $\begin{array}{l}\text { Coherence and continuity of government action in economic } \\
\text { matters }\end{array}$ & from 1 to 4 \\
\hline A5102 & Authority of the political powers over the administration & from 1 to 4 \\
\hline A511 & Ability of the society for innovation and adaptation. & from $1=$ to 4 \\
\hline A5 5110 & $\begin{array}{l}\text { Ability of the society for innovation and adaptation in } \\
\text { technological matters }\end{array}$ & from 1 to 4 \\
\hline A5111 & $\begin{array}{l}\text { Ability of the society for innovation and adaptation in managerial } \\
\text { matters }\end{array}$ & from 1 to 4 \\
\hline A5112 & $\begin{array}{l}\text { Ability of the society for adaptation and innovation in legal and } \\
\text { institutional matters }\end{array}$ & from 1 to 4 \\
\hline A512 & Long-term strategic vision of the government & from 1 to 4 \\
\hline A5120 & Does public power act in accordance with a strategic vision? & from 1 to 4 \\
\hline A514 & The principal objectives of the local elites & from 1 to 4 \\
\hline A5140 & $\begin{array}{l}\text { Are economic growth and development a main concern for the } \\
\text { political power }\end{array}$ & from 1 to 4 \\
\hline A5141 & $\begin{array}{l}\text { Are economic growth and development a main concern for the } \\
\text { local public elites (government officials, universities, etc)? }\end{array}$ & from 1 to 4 \\
\hline A515 & investment in the future of the population & from $1=$ low level of action to $4=$ high level of action \\
\hline A5 150 & Do parents invest a great deal in their children's education? & from 1 to 4 \\
\hline A5151 & $\begin{array}{l}\text { Do parents steer their children more towards the civil service or } \\
\text { the private sector? }\end{array}$ & from 1 to 4 \\
\hline B500 & Technological environment, diffusion of technology & from 1 to 4 \\
\hline B5000 & Technical supervisionrate(engineers, technicians) in SMEs/SMIs & from $1=$ low to $4=$ high \\
\hline
\end{tabular}


B5001 Technical supervision rate (engineers, technicians) in large from 1=low to 4=high companies

B5002 concentration and "continuity" of business fabric (local from 1=low concentration, continuity to 4=high subcontracting and maintenance, etc)

C500 Diffusion of technology, innovation

C5000 Level of competence of bank executives

C501 Innovation: venture capital from 1 to 4

from $1=$ low level of competence to $4=$ high level

0 if no arrangements - if arrangements exist, score from $1=$ very weak to $4=$ very substantial

C5010 Financial arrangements encouraging venture capital from 0 to 4

\section{Appendix B}

Table B1. total variance explained (année-2001)

\begin{tabular}{|c|c|c|c|}
\hline \multirow{2}{*}{ Component } & \multicolumn{3}{|c|}{ Initial eigenvalues } \\
\hline & Total & $\%$ of Variance & Cumulative \% \\
\hline 1 & 14.530 & 51.894 & 51.894 \\
\hline 2 & 2.140 & 7.642 & 59.535 \\
\hline 3 & 1.421 & 5.074 & 64.609 \\
\hline 4 & 1.205 & 4.304 & 68.913 \\
\hline 5 & 1.047 & 3.738 & 72.651 \\
\hline 6 & 1.021 & 3.646 & 76.297 \\
\hline 7 & .845 & 3.019 & 79.315 \\
\hline 8 & .742 & 2.650 & 81.965 \\
\hline 9 & .610 & 2.177 & 84.142 \\
\hline 10 & .544 & 1.943 & 86.085 \\
\hline 11 & .484 & 1.728 & 87.813 \\
\hline 12 & .448 & 1.600 & 89.413 \\
\hline 13 & .418 & 1.494 & 90.907 \\
\hline 14 & .343 & 1.225 & 92.132 \\
\hline 15 & .303 & 1.081 & 93.212 \\
\hline 16 & .265 & .946 & 94.158 \\
\hline 17 & .245 & .874 & 95.033 \\
\hline 18 & .234 & .835 & 95.868 \\
\hline 19 & .197 & .703 & 96.571 \\
\hline 20 & .185 & .661 & 97.232 \\
\hline 21 & .147 & .524 & 97.755 \\
\hline 22 & .141 & .505 & 98.260 \\
\hline 23 & .127 & .453 & 98.713 \\
\hline 24 & .105 & .376 & 99.089 \\
\hline 25 & .085 & .303 & 99.392 \\
\hline 26 & .068 & .244 & 99.636 \\
\hline 27 & .058 & .206 & 99.842 \\
\hline 28 & .044 & .158 & 100.000 \\
\hline
\end{tabular}

Table B2. Rotated component matrix (survey2001)

\begin{tabular}{lcccccc}
\hline & \multicolumn{6}{c}{ Component } \\
& 1 & 2 & 3 & 4 & 5 & 6 \\
\hline $\mathrm{A} 3020$ & .679 & .457 & .307 & .285 & .127 & .138 \\
$\mathrm{~A} 3021$ & .415 & .324 & .506 & .367 & .231 & .220 \\
$\mathrm{~A} 3040$ & .454 & .434 & .248 & .469 & .172 & .307 \\
$\mathrm{~A} 3041$ & .502 & .443 & .231 & .488 & .049 & .125 \\
$\mathrm{~A} 3042$ & .479 & .602 & .157 & .468 & .105 & .179 \\
$\mathrm{~A} 3043$ & .497 & .437 & .317 & .349 & .027 & -.057 \\
$\mathrm{~A} 6010$ & .633 & .234 & .273 & .389 & .258 & .106 \\
\hline
\end{tabular}




\begin{tabular}{lllllll}
\hline A6011 & .804 & .169 & .092 & .250 & .274 & .103 \\
A6012 & .778 & .166 & .234 & .217 & .284 & .070 \\
A6013 & .745 & .144 & .426 & -.007 & -.045 & .074 \\
A9040 & .167 & .473 & .099 & .193 & .710 & .091 \\
A9041 & .021 & .262 & .077 & .107 & .801 & .301 \\
A9042 & .326 & .056 & .280 & .254 & .721 & .081 \\
D6010 & -.215 & .458 & .167 & -.297 & .282 & .583 \\
D6011 & .282 & .007 & -.047 & .159 & .192 & .808 \\
A5100 & .225 & .145 & .612 & .490 & .253 & .079 \\
A5101 & .203 & .041 & .500 & .594 & .373 & -.080 \\
A5102 & .199 & .093 & .121 & .869 & .154 & .105 \\
A5110 & .099 & .683 & .216 & .177 & .263 & .194 \\
A5111 & .271 & .212 & .792 & .150 & .085 & .047 \\
A5112 & .263 & .250 & .761 & .183 & .263 & -.075 \\
A5120 & .166 & .347 & .352 & .623 & .167 & -.066 \\
A5150 & .320 & .654 & .082 & .140 & .195 & -.133 \\
B5000 & .351 & .547 & .391 & .063 & .323 & .094 \\
B5001 & .334 & .531 & .311 & .129 & .374 & .232 \\
B5002 & .480 & .404 & .190 & .021 & .450 & .056 \\
C5000 & .489 & .135 & .523 & .281 & -.018 & .360 \\
C5010 & .485 & .225 & .384 & .277 & .435 & -.121 \\
\hline
\end{tabular}

Extraction Method: Principal Component Analysis. Rotation Method: Varimax with Kaiser Normalization.

\section{Appendix C}

Table C1. KMO and Barlett'stest (survey 2006)

\begin{tabular}{lll}
\hline Kaiser-Meyer-Olkin Measure of Sampling Adequacy. & .885 \\
\hline Bartlett's Test of Sphericity & Approx. Chi-Square & 2883.449 \\
& Df & 780 \\
& Sig. & .000 \\
\hline
\end{tabular}

Table C2. Total variance explained (survey 2006)

\begin{tabular}{cccc}
\hline Component & Total & $\begin{array}{c}\text { Initial eigenvalues } \\
\text { \% of Variance }\end{array}$ & Cumulative \% \\
\hline 1 & 17.949 & 44.872 & 44.872 \\
2 & 2.346 & 5.865 & 50.737 \\
3 & 2.175 & 5.438 & 56.175 \\
4 & 1.710 & 4.276 & 60.451 \\
5 & 1.594 & 3.986 & 64.438 \\
6 & 1.380 & 3.449 & 67.886 \\
7 & 1.244 & 3.110 & 70.997 \\
8 & 1.068 & 2.669 & 73.666 \\
9 & .931 & 2.328 & 75.994 \\
10 & .832 & 2.079 & 78.073 \\
11 & .778 & 1.945 & 80.019 \\
12 & .690 & 1.724 & 81.742 \\
13 & .637 & 1.592 & 83.334 \\
14 & .599 & 1.497 & 84.832 \\
15 & .563 & 1.406 & 86.238 \\
16 & .540 & 1.350 & 87.588 \\
17 & .477 & 1.193 & 88.780 \\
18 & .423 & 1.058 & 89.838 \\
19 & .394 & .985 & 90.823 \\
20 & .365 & .914 & 91.737 \\
\hline
\end{tabular}




\begin{tabular}{llll}
\hline 21 & .329 & .823 & 92.559 \\
22 & .318 & .794 & 93.353 \\
23 & .302 & .756 & 94.109 \\
24 & .282 & .704 & 94.813 \\
25 & .265 & .662 & 95.475 \\
26 & .240 & .599 & 96.074 \\
27 & .216 & .540 & 96.614 \\
28 & .196 & .491 & 97.105 \\
29 & .185 & .464 & 97.568 \\
30 & .168 & .420 & 97.989 \\
31 & .151 & .378 & 98.366 \\
32 & .122 & .305 & 98.671 \\
33 & .114 & .284 & 98.956 \\
34 & .099 & .248 & 99.203 \\
35 & .080 & .201 & 99.405 \\
36 & .070 & .175 & 99.579 \\
37 & .066 & .165 & 99.744 \\
38 & .050 & .125 & 99.869 \\
39 & .033 & .083 & 99.952 \\
40 & .019 & .048 & 100.000 \\
\hline
\end{tabular}

Table C3. Rotated component matrix (survey 2006)

\begin{tabular}{|c|c|c|c|c|c|c|c|c|}
\hline & \multicolumn{8}{|c|}{ Component } \\
\hline & 1 & 2 & 3 & 4 & 5 & 6 & 7 & 8 \\
\hline A 5050 & .334 & .719 & .116 & .110 & -.019 & .160 & -.071 & -.051 \\
\hline A5060 & .356 & .289 & -.220 & .069 & .306 & -.007 & .383 & -.546 \\
\hline A5080 & .617 & .546 & .066 & .201 & .086 & .038 & .001 & .230 \\
\hline A5081 & .583 & .415 & .104 & .341 & .266 & .043 & .044 & .142 \\
\hline A5100 & .304 & .606 & .428 & .291 & .106 & .121 & .144 & .092 \\
\hline A5101 & .245 & .636 & .281 & .247 & .161 & .172 & .135 & -.054 \\
\hline A5 5102 & .659 & .170 & .091 & .294 & -.008 & .098 & .126 & -.013 \\
\hline A5110 & .246 & .376 & .014 & .572 & .163 & .162 & .146 & .285 \\
\hline A5111 & .414 & .299 & .233 & .425 & -.002 & .363 & .077 & .267 \\
\hline A5112 & .438 & .337 & .235 & .362 & .111 & .238 & -.126 & .114 \\
\hline A5120 & .242 & .830 & .097 & .051 & .027 & .005 & .108 & .082 \\
\hline A5140 & .030 & .726 & .375 & .229 & .191 & .016 & -.046 & .109 \\
\hline A5141 & .279 & .594 & .171 & .436 & .085 & .118 & -.088 & .060 \\
\hline A 5150 & .017 & .297 & -.017 & .592 & -.201 & .116 & .246 & -.030 \\
\hline A5151 & .169 & .209 & -.024 & .120 & .109 & .116 & .212 & .752 \\
\hline B5000 & .363 & .055 & .228 & .641 & .241 & .232 & .112 & -.002 \\
\hline B5001 & .250 & .092 & .177 & .662 & .236 & .214 & -.268 & .048 \\
\hline B5002 & .208 & .351 & .202 & .647 & .191 & .072 & .055 & .083 \\
\hline C5000 & .352 & .044 & .472 & .014 & -.058 & .511 & .158 & .211 \\
\hline C5010 & .206 & .444 & .351 & .295 & .010 & .357 & -.194 & .001 \\
\hline A 3020 & .551 & .305 & .535 & .046 & .284 & .210 & .067 & .094 \\
\hline A3021 & .580 & .383 & .435 & .076 & .245 & .102 & -.028 & .050 \\
\hline A 3040 & .637 & .159 & .442 & .182 & .142 & .140 & .109 & .245 \\
\hline A3041 & .723 & .216 & .249 & .016 & .187 & .167 & -.101 & -.083 \\
\hline A 3042 & .692 & .265 & .308 & .104 & .183 & .285 & .124 & -.011 \\
\hline A3043 & .745 & .142 & .220 & .344 & .056 & .120 & -.056 & -.026 \\
\hline A6010 & .446 & .273 & .553 & .179 & .081 & .148 & .099 & .134 \\
\hline A6011 & .158 & .136 & .850 & .119 & .070 & .233 & .143 & -.039 \\
\hline A 6012 & .200 & .257 & .843 & .119 & .070 & .197 & .090 & -.040 \\
\hline A6013 & .339 & .180 & .727 & .179 & .192 & -.111 & -.102 & .078 \\
\hline A9040 & .271 & .351 & .491 & .337 & .496 & .046 & .166 & .075 \\
\hline
\end{tabular}




\begin{tabular}{llllllllll}
\hline $\mathrm{A} 9041$ & .341 & .212 & .230 & .288 & .593 & .240 & .081 & -.007 \\
$\mathrm{~A} 9042$ & .181 & .033 & .420 & .580 & .412 & -.012 & .239 & -.084 \\
$\mathrm{~B} 6070$ & .196 & .347 & .247 & .358 & .354 & .100 & .470 & .120 \\
$\mathrm{~B} 6071$ & .011 & .040 & -.138 & -.069 & -.024 & -.051 & -.778 & -.097 \\
$\mathrm{~B} 6072$ & .152 & .381 & .520 & .406 & .239 & .179 & -.021 & -.003 \\
$\mathrm{C} 7010$ & .226 & .160 & .187 & .235 & .261 & .809 & .017 & .086 \\
$\mathrm{C} 7011$ & .187 & .136 & .151 & .243 & .287 & .837 & .046 & .024 \\
$\mathrm{D} 6010$ & .081 & -.018 & -.067 & .123 & .732 & .379 & .194 & -.040 \\
$\mathrm{D} 6011$ & .111 & .105 & .255 & .060 & .808 & .054 & -.133 & .077 \\
\hline
\end{tabular}

\section{Appendix D}

Table D1. KMO and Barlett's test (survey 2009)

\begin{tabular}{lll}
\hline Kaiser-Meyer-Olkin Measure of Sampling Adequacy. & .926 \\
\hline Bartlett's Test of Sphericity & Approx. Chi-Square & 6538.508 \\
& Df & 1326 \\
& Sig. & .000 \\
\hline
\end{tabular}

Table D2. Total Variance explained (survey 2009)

\begin{tabular}{|c|c|c|c|}
\hline \multirow{2}{*}{ Component } & \multicolumn{3}{|c|}{ Initial Eigenvalues } \\
\hline & Total & $\%$ of Variance & Cumulative $\%$ \\
\hline 1 & 25.730 & 49.480 & 49.480 \\
\hline 2 & 4.143 & 7.967 & 57.447 \\
\hline 3 & 2.505 & 4.818 & 62.265 \\
\hline 4 & 1.741 & 3.349 & 65.613 \\
\hline 5 & 1.638 & 3.149 & 68.762 \\
\hline 6 & 1.191 & 2.290 & 71.053 \\
\hline 7 & 1.039 & 1.997 & 73.050 \\
\hline 8 & .939 & 1.806 & 74.856 \\
\hline 9 & .894 & 1.719 & 76.575 \\
\hline 10 & .824 & 1.586 & 78.161 \\
\hline 11 & .745 & 1.433 & 79.593 \\
\hline 12 & .737 & 1.418 & 81.011 \\
\hline 13 & .666 & 1.281 & 82.292 \\
\hline 14 & .622 & 1.196 & 83.487 \\
\hline 15 & .592 & 1.138 & 84.625 \\
\hline 16 & .544 & 1.046 & 85.671 \\
\hline 17 & .514 & .988 & 86.659 \\
\hline 18 & .503 & .968 & 87.627 \\
\hline 19 & .462 & .889 & 88.515 \\
\hline 20 & .427 & .820 & 89.336 \\
\hline 21 & .411 & .790 & 90.126 \\
\hline 22 & .355 & .683 & 90.809 \\
\hline 23 & .342 & .658 & 91.467 \\
\hline 24 & .337 & .648 & 92.115 \\
\hline 25 & .309 & .594 & 92.709 \\
\hline 26 & .286 & .550 & 93.259 \\
\hline 27 & .284 & .546 & 93.805 \\
\hline 28 & .258 & .497 & 94.301 \\
\hline 29 & .243 & .467 & 94.768 \\
\hline 30 & .236 & .453 & 95.221 \\
\hline 31 & .221 & .425 & 95.646 \\
\hline 32 & .196 & .376 & 96.022 \\
\hline 33 & .187 & .360 & 96.382 \\
\hline
\end{tabular}




\begin{tabular}{llll}
\hline 34 & .180 & .347 & 96.728 \\
35 & .165 & .318 & 97.046 \\
36 & .162 & .312 & 97.358 \\
37 & .156 & .301 & 97.659 \\
38 & .142 & .273 & 97.932 \\
39 & .139 & .268 & 98.200 \\
40 & .119 & .229 & 98.429 \\
41 & .112 & .215 & 98.644 \\
42 & .106 & .204 & 98.848 \\
43 & .095 & .183 & 99.032 \\
44 & .085 & .163 & 99.195 \\
45 & .074 & .142 & 99.337 \\
46 & .072 & .139 & 99.476 \\
47 & .069 & .132 & 99.608 \\
48 & .061 & .116 & 99.724 \\
49 & .056 & .107 & 99.832 \\
50 & .042 & .080 & 99.912 \\
51 & .033 & .064 & 99.976 \\
52 & .012 & 024 & 100.000 \\
\hline
\end{tabular}

Table D3. Rotated component matrix (survey 2009)

\begin{tabular}{|c|c|c|c|c|c|c|c|}
\hline & \multicolumn{7}{|c|}{ Component } \\
\hline & 1 & 2 & 3 & 4 & 5 & 6 & 7 \\
\hline A 3020 & .677 & .279 & .341 & .155 & .306 & .016 & .185 \\
\hline A3021 & .635 & .324 & .300 & -.077 & .275 & -.015 & .225 \\
\hline A 3022 & .638 & .347 & .236 & -.028 & .379 & -.080 & .068 \\
\hline A 3023 & .574 & .216 & .475 & .211 & .292 & -.067 & -.029 \\
\hline B6090 & .508 & .260 & .229 & .515 & .101 & .049 & .184 \\
\hline B6091 & .494 & .292 & .203 & .512 & .124 & .005 & .247 \\
\hline B6092 & .651 & .033 & .266 & .323 & .028 & .072 & .181 \\
\hline B6093 & .560 & .057 & -.027 & .297 & .197 & .058 & .019 \\
\hline D6001 & .101 & .097 & .176 & .710 & .061 & -.130 & .071 \\
\hline D6002 & .526 & .126 & .216 & .411 & .023 & -.050 & .210 \\
\hline A9060 & .396 & .143 & .528 & .446 & .211 & .096 & .273 \\
\hline A9061 & .322 & .106 & .454 & .455 & .328 & -.030 & .321 \\
\hline A9062 & .405 & .060 & .419 & .537 & .251 & .122 & .292 \\
\hline C7010 & .362 & .383 & -.020 & .564 & .379 & -.033 & .132 \\
\hline C7011 & .361 & .400 & -.010 & .556 & .383 & .001 & .105 \\
\hline A6000 & .661 & .370 & .146 & .254 & .126 & .068 & .309 \\
\hline A6001 & .617 & .071 & .143 & .184 & .541 & .070 & .127 \\
\hline A6002 & .610 & .143 & .157 & .264 & .548 & .064 & .095 \\
\hline A6003 & .603 & .230 & .190 & .145 & .349 & -.022 & .379 \\
\hline A 6010 & .697 & .286 & .177 & .169 & .291 & .052 & .166 \\
\hline A6011 & .708 & .135 & .154 & .259 & .051 & .103 & .258 \\
\hline A6012 & .723 & .267 & .077 & .127 & .033 & .050 & .156 \\
\hline A 5000 & .187 & .787 & .362 & .088 & .175 & -.003 & .102 \\
\hline A5001 & .125 & .804 & .242 & .152 & .007 & -.024 & .061 \\
\hline A5002 & .316 & .757 & .262 & .228 & .118 & -.091 & .049 \\
\hline A5010 & .461 & .499 & .423 & .041 & .225 & .158 & .118 \\
\hline A5011 & .411 & .400 & .553 & .174 & .120 & .077 & .098 \\
\hline A5020 & .296 & .446 & .596 & .018 & .199 & .218 & .010 \\
\hline A5021 & .549 & .356 & .543 & .019 & -.009 & .163 & -.077 \\
\hline A5022 & .370 & .461 & .506 & .107 & .050 & .166 & .141 \\
\hline A5030 & .405 & .392 & .564 & -.021 & .242 & .165 & .124 \\
\hline A5031 & .519 & .244 & .411 & .358 & .224 & -.102 & -.072 \\
\hline
\end{tabular}




\begin{tabular}{llllllll}
\hline A5032 & .370 & .275 & .495 & .319 & .146 & .090 & -.022 \\
A5033 & .431 & .385 & .404 & .095 & .398 & .180 & .233 \\
A5040 & .249 & .412 & .403 & .241 & .507 & .149 & .082 \\
A5041 & .279 & .458 & .384 & .198 & .428 & .084 & .015 \\
A5042 & .252 & .631 & .154 & .234 & .295 & -.018 & .355 \\
A5050 & .013 & .178 & .804 & .155 & .118 & .065 & .169 \\
A5051 & .061 & .177 & .736 & .210 & .026 & .265 & .229 \\
A5080 & .223 & .491 & .248 & .335 & .467 & -.002 & .145 \\
A5081 & .468 & .441 & .096 & .363 & .271 & -.015 & .292 \\
A5082 & .361 & .435 & .258 & .417 & .264 & -.059 & .285 \\
B5000 & .328 & .274 & .237 & .427 & .352 & -.067 & .338 \\
B5001 & .310 & .189 & .252 & .312 & .538 & -.010 & .294 \\
B5002 & .279 & .433 & .279 & .206 & .508 & .012 & .326 \\
C5000 & .439 & .199 & .098 & .168 & .144 & -.007 & .724 \\
C5001 & .228 & .103 & .246 & .204 & .118 & .078 & .761 \\
C5010 & .312 & .436 & -.011 & .237 & .371 & .084 & .384 \\
C5020 & .078 & .036 & .093 & -.005 & .044 & .945 & .068 \\
C5021 & .045 & .041 & .100 & .007 & .075 & .944 & .079 \\
C5022 & .000 & -.007 & .100 & -.080 & -.035 & .927 & -.005 \\
C5023 & .030 & -.047 & .127 & -.031 & -.005 & .902 & -.070 \\
\hline
\end{tabular}

Note. Extraction Method: Principal Component Analysis. Rotation Method: Varimax with Kaiser Normalization.

a. Rotation converged in 14 iterations.

\section{Copyrights}

Copyright for this article is retained by the author(s), with first publication rights granted to the journal.

This is an open-access article distributed under the terms and conditions of the Creative Commons Attribution license (http://creativecommons.org/licenses/by/3.0/). 